\title{
LPS Induces Pulp Progenitor Cell Recruitment via Complement Activation
}

\author{
F. Chmilewsky', C. Jeanneau', P. Laurent ${ }^{1,2}$, and I. About
}

\begin{abstract}
Complement system, a major component of the natural immunity, has been recently identified as an important mediator of the dentin-pulp regeneration process through STRO-I pulp cell recruitment by the C5a active fragment. Moreover, it has been shown recently that under stimulation with lipoteichoic acid, a complex component of the Gram-positive bacteria cell wall, human pulp fibroblasts are able to synthesize all proteins required for complement activation. However, Gram-negative bacteria, which are also involved in tooth decay, are known as powerful activators of complement system and inflammation. Here, we investigated the role of Gram-negative bacteria-induced complement activation on the pulp progenitor cell recruitment using lipopolysaccharide (LPS), a major component of all Gram-negative bacteria. Our results show that incubating pulp fibroblasts with LPS induced membrane attack complex formation and C5a release in serum-free fibroblast cultures. The produced C5a binds to the pulp progenitor cells' membrane and induces their migration toward the LPS stimulation chamber, as revealed by the dynamic transwell migration assays. The inhibition of this migration by the C5aR-specific antagonist W540II indicates that the pulp progenitor migration is mediated by the interaction between C5a and C5aR. Our findings demonstrate, for the first time, a direct interaction between the recruitment of progenitor pulp cells and the activation of complement system generated by pulp fibroblast stimulation with LPS.
\end{abstract}

Keywords: stem cell(s), pulp biology, regeneration, caries, complement C5a, chemotaxis

\section{Introduction}

The complement system is a crucial component of innate immunity and inflammation (Ricklin et al. 2010; Sarma and Ward 2011). It is activated by various stimuli through 3 main pathways: the classical, the alternative, and the lectin pathways (Kenneth et al. 2012). It is known as one of the most effective initial mechanisms for eliminating invading pathogens and altered host cells by formation of the cytolytic membrane attack complex (MAC) (Tomlinson 1993) and the recruitment of immune cells by the release of anaphylatoxins such as C3a and C5a (Ehrengruber et al. 1994; Hartmann et al. 1997; Nataf et al. 1999).

Moreover, it has been shown that complement activation is involved in the regeneration of tissues such as cardiac (Lara-Astiaso et al. 2012), bone (Ignatius et al. 2011), and liver (Mastellos et al. 2001). Furthermore, complement system activation has been reported in tooth decay (Chmilewsky et al. 2013), and functional studies have suggested that complement activation may be implicated in one of the early steps of dentin-pulp regeneration: pulp progenitor cell recruitment (Chmilewsky et al. 2013) from their niches to the injured site (Shi and Gronthos 2003; Téclès et al. 2005). This migration was demonstrated to be guided by a gradient of complement soluble active fragment C5a and suggested an activation of complement system from plasma (Chmilewsky et al. 2013, 2014a). Although these circulating proteins are mainly known to be synthesized by the liver (Alper et al. 1969), it has been shown that a wide range of tissues/cells synthesizes complement proteins (Würzner 2000; Li et al. 2007). Interestingly, while so far only some immune cells seem to be able to produce all the components required for an effective complement system activation ( $\mathrm{Li}$ et al. 2007), a recently conducted study demonstrated that dental pulp tissue comprises a unique non-immune cell type, the human pulp fibroblast, able to produce and activate efficiently the complement system proteins (Chmilewsky et al. 2014b). This

\footnotetext{
'Aix Marseille Université, CNRS, ISM UMR 7287, Marseille, France ${ }^{2}$ APHM, Hôpital Timone, Service d'Odontologie, Marseille, France
} 
was demonstrated in primary cultures of human fibroblasts under serum-free conditions by reverse transcriptionpolymerase chain reaction (RT-PCR) analysis, MAC formation, and pulp progenitor cell recruitment (Chmilewsky et al. 2014b). These results were obtained after stimulating human pulp fibroblasts with lipoteichoic acid (LTA), a complex component of Gram-positive bacteria cell wall. It should be precised, however, that this does not exclude complement protein synthesis by other pulp cell types.

Although Gram-positive bacteria, such as Streptococcus mutans, Actinomyces viscosus, and Lactobacillus acidophilus (Loesche 1986; Martin et al. 2002), constitute the predominant part of cariogenic bacteria, several studies demonstrated that Gram-negative bacteria, such as Prevotella and Porphyromonas, are also involved in this cariogenic pathology (Martin et al. 2002). Even if fewer Gram-negative than Gram-positive bacteria seem to be found in carious injury sites (Martin et al. 2002), their implications in the inflammatory process have been clearly demonstrated (Tokuda et al. 2001; Silva et al. 2009). Indeed, it has been shown that when dental pulp cells are stimulated with lipopolysaccharide (LPS), a component of the Gram-negative bacteria cell wall, they produce significant quantities of proinflammatory cytokines, especially interleukin (IL) -8 , IL-6, and IL-1 $\beta$ (Tokuda et al. 2001; Silva et al. 2009). Since Gram-negative bacteria are known as powerful activators of complement system (Kang et al. 2006; Pangburn et al. 2008), we set out this work to investigate the role of LPS of Gram-negative bacteria in the interactions between pulp progenitor cells, pulp fibroblasts, and complement system during the dentin-pulp regeneration process.

Our hypothesis was that LPS of Gram-negative bacteria may induce complement activation and play a role in pulp progenitor cell recruitment in case of deep carious injury.

\section{Materials and Methods}

\section{Materials}

Cell culture materials and reagents were from PAA Laboratories (Les Mureaux, France). Primary antibodies were from R\&D Systems (Lille, France) or Abcam (Cambridge, UK). Secondary antibodies were from Life Technologies (Saint-Aubin, France). LPS was from SigmaAldrich (St. Louis, MO), and chemicals were from Carlo Erba Reagents (Val-de-Reuil, France).

\section{Collection of Molar Teeth and Bacteria Staining}

Human immature third molars freshly extracted for orthodontic reasons and carious teeth were obtained in compliance with French legislation (including informed consent and institutional review board approval of the protocol used). Teeth were fixed and routinely processed as described previously (Téclès et al. 2005).
Intact and carious tooth sections were stained using a tissue Gram stain kit (Sigma-Aldrich) according to the manufacturer's instructions.

\section{Primary Pulp Cell Culture}

Human pulp cells were prepared from immature third molars at the two-thirds root formation stage by the explant outgrowth method (About et al. 2000). The teeth were obtained from at least 3 different donors for each experiment (4 molars/donor). Teeth were obtained in compliance with French legislation (including informed consent and institutional review board approval of the protocol used).

\section{Magnetic Cell Sorting}

Pulp progenitor cells were directly sorted from primary pulp cell cultures at passages 1 to 5 with mouse anti-human STRO-1 IgM with immune magnetic beads according to the manufacturer's protocol (Dynal, Oslo, Norway).

\section{Pulp Cell Characterization}

STRO-1 sorted and nonsorted pulp cells were grown in 8-well glass culture chambers up to $70 \%$ confluence.

In these 2 cultures, cells were rinsed with phosphatebuffered saline (PBS) and fixed with $4 \%$ paraformaldehyde during $15 \mathrm{~min}$ at $4^{\circ} \mathrm{C}$. Then nonspecific binding sites were blocked with $1 \%$ bovine serum albumin (BSA) for $1 \mathrm{~h}$. While nonsorted pulp cells were incubated for $1 \mathrm{~h}$ with primary antibody against fibroblast surface protein (FSP; $2 \mu \mathrm{g} / \mathrm{mL}$ ), STRO-1 sorted cells were incubated with primary antibodies against STRO-1 $(5 \mu \mathrm{g} / \mathrm{mL})$ and CD44 $(2.5 \mu \mathrm{g} / \mathrm{mL})$, CD90 $(2.5 \mu \mathrm{g} / \mathrm{mL}), \mathrm{CD} 105(2.5 \mu \mathrm{g} / \mathrm{mL}), \mathrm{CD} 146(2.5 \mu \mathrm{g} / \mathrm{mL})$, or CD166 $(2.5 \mu \mathrm{g} / \mathrm{mL})$. Controls were incubated with the respective primary antibody isotypes. After washing, cells were incubated for $45 \mathrm{~min}$ with their respective secondary antibody, Alexa Fluor 488 or Alexa Fluor $594(2 \mu \mathrm{g} / \mathrm{mL})$, and with DAPI $(1 \mu \mathrm{g} / \mathrm{mL})$ for fluorescence microscopy detection.

\section{Detection of MAC Formation}

Human pulp cells were grown in 8-well glass culture chambers up to $50 \%$ confluence. After 3 washes with PBS to remove all serum residues, the cells were incubated in serum-free minimum essential medium (MEM; $150 \mu \mathrm{L} /$ well $) \pm$ LPS $\left(10^{4} \mathrm{EU} / \mathrm{mL}\right)$ and \pm soluble CD59 $(6 \mu \mathrm{g} / \mathrm{mL})$, as an inhibitor of MAC formation. After $1 \mathrm{~h}$, the cells were fixed with $4 \%$ paraformaldehyde during $15 \mathrm{~min}$ at $4^{\circ} \mathrm{C}$ and saturated with $1 \% \mathrm{BSA} / 0.3 \mathrm{M}$ glycine in $0.1 \%$ PBS-Tween for $1 \mathrm{~h}$. Then, pulp cells were incubated with an anti-C5b-9 $(50 \mu \mathrm{g} / \mathrm{mL})$ or its isotype for $1 \mathrm{~h}$. Finally, pulp cells were incubated for $45 \mathrm{~min}$ with secondary antibody Alexa Fluor $488(2 \mu \mathrm{g} / \mathrm{mL})$ and DAPI $(1 \mu \mathrm{g} / \mathrm{mL})$. 


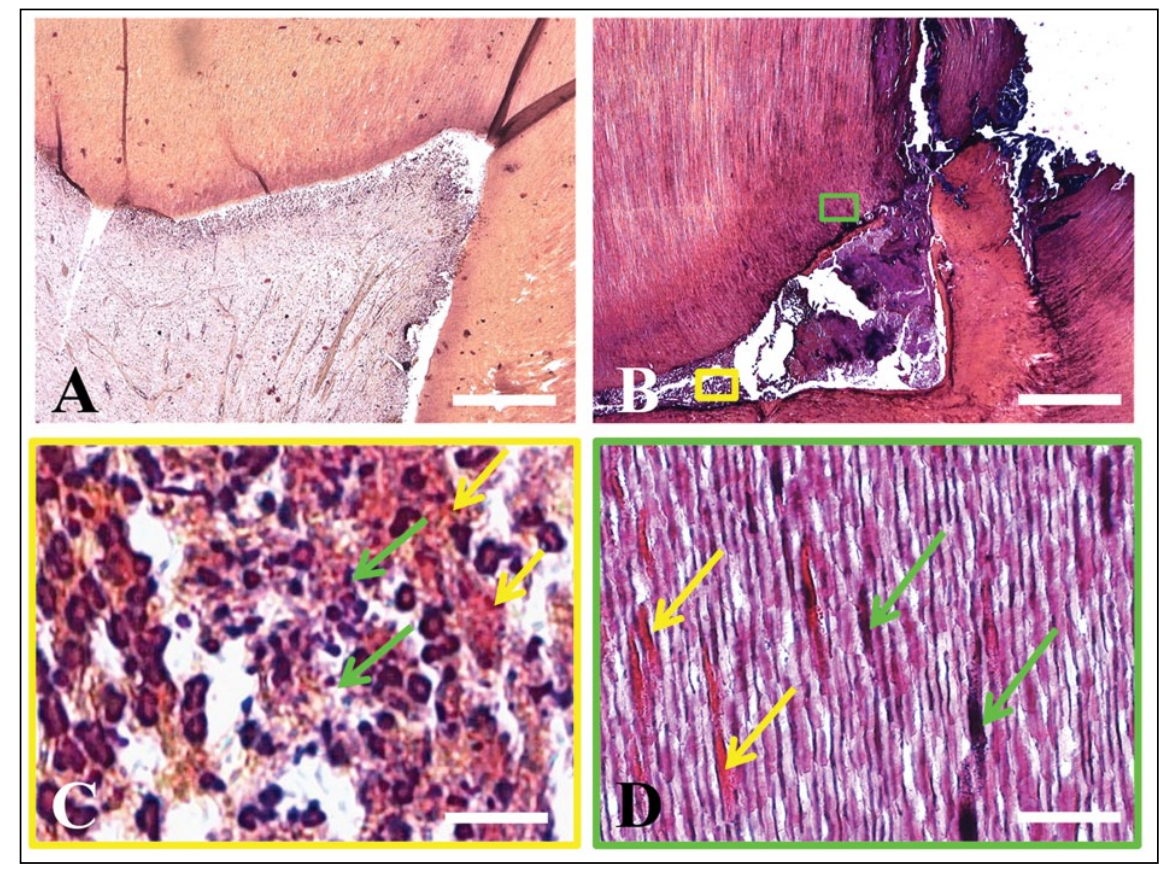

Figure I. Gram staining of carious teeth sections. Representative images of Gram staining on intact (A) and carious teeth (B-D). In the intact tooth section, dentin structure appears tubular and regular surrounding an intact pulp tissue $(A)$. In the carious tooth, the histologic sections show a deep carious lesion, a discontinuous and partially destroyed dentin $(B)$, and an inflamed pulp $(B, C)$. Bacteria infiltration is visible both in the dentin tubules and in the pulp tissue. While bacteria could not be detected in intact teeth (A), both Gram-positive (green arrows) and Gram-negative bacteria (yellow arrows) were detected in carious teeth. These are clearly visible at higher magnifications in pulp tissue (C) and dentin (D). Scale bars: A and B $=500 \mu \mathrm{m}, C$ and $D=20 \mu \mathrm{m}$. of migrating STRO-1 sorted cells to the lower surface of the membrane was counted in 5 random fields under a light microscope $(\times 200)$.

\section{Statistical Analysis}

All experiments were repeated at least 3 times, and statistical significance was determined using the Student's $t$ test to compare the different treatments and their respective controls. Data were expressed as means $\pm \mathrm{SD}$ and considered significant for $P<0.05$.

\section{Results}

\section{Gram-Negative Bacteria Were Detected in Human Carious Teeth}

While no bacteria were detected in human intact teeth (Fig. 1A), an intense purple labeling, corresponding to the presence of Grampositive bacteria, was observed in carious teeth (Fig. 1B). Although the observed labeling was mainly purple (Fig. 1B), a higher magnification revealed also a red labeling

\section{C5a Enzyme-Linked Immunosorbent Assay}

Human pulp cells were grown in 12-well dishes. At subconfluency, cells were washed 3 times with PBS and then incubated in serum-free MEM $(500 \mu \mathrm{L} /$ well $) \pm$ LPS $\left(10^{4} \mathrm{EU} /\right.$ $\mathrm{mL}$ ). After $20 \mathrm{~min}, 1 \mathrm{~h}$, and $24 \mathrm{~h}$, the supernatants were harvested and $\mathrm{C} 5 \mathrm{a}$ concentrations immediately determined by enzyme-linked immunosorbent assay (ELISA) according to the manufacturer's instructions (R\&D Systems, Lille, France).

\section{Migration Assays}

Migration was assayed in 24-well plates equipped with transwell inserts with an $8-\mu \mathrm{m}$ pore-size membrane. STRO-1 sorted cells $\left(10^{4}\right.$ cells/well $)$ were resuspended in serum-free MEM and seeded in the upper chamber with or without 10 nM W54011, a C5aR-specific antagonist (supplementary data). The lower chambers were loaded with or without nonsorted pulp cells in serum-free MEM \pm LPS $10^{4} \mathrm{EU} / \mathrm{mL}$ (supplementary data). After $24 \mathrm{~h}$, nonmigrating STRO-1 sorted cells on the upper side of the insert membrane were wiped off using a cotton bud, and STRO-1 sorted cells on the lower surface of the same membrane were fixed with methanol and stained with hematoxylin (supplementary data). The number both in the pulp tissue (Fig. 1C) and in the dentin tubules (Fig. 1D), indicating clearly the presence of Gram-negative bacteria.

\section{Human Pulp Cell Characterization In Vitro}

As indicated on representative immunofluorescence images, all nonsorted human pulp cells used in the experiments expressed FSP (Fig. 2A). So hereafter, nonsorted human pulp cells will be designated as "pulp fibroblasts." The cell population obtained from the growth of magnetic STRO-1 sorted cells expressed both the mesenchymal stem cell marker STRO-1 (green fluorescence) and 5 other stem cell markers: CD44, CD90, CD105, CD146, and CD166 (red fluorescence) (Fig. 2B). These STRO-1 sorted cells will be designated hereafter as "pulp progenitor cells."

\section{Complement System Is Activated under Serum- Free Conditions after LPS Stimulation of Human Pulp Fibroblasts}

Under serum-free conditions, no MAC formation was detected on unstimulated human pulp fibroblasts (Fig. 3Aa, $3 \mathrm{Ac}$ ). However, when these cells were stimulated for $1 \mathrm{~h}$ 
with LPS, an intense MAC labeling was observed on the cell surface (Fig. 3Ab, 3Af). This staining drastically decreased upon coincubation of pulp fibroblasts with soluble CD59 used as a MAC formation inhibitor (Fig. 3Ad).

Moreover, after pulp fibroblast stimulation with LPS for $20 \mathrm{~min}$, a significant increase of $\mathrm{C} 5 \mathrm{a}$ was obtained by ELISA under serumfree conditions compared with that detected in unstimulated pulp fibroblast cultures $(183.6 \pm 56.2$ $\mathrm{pg} / \mathrm{mL}$ vs. $59.8 \pm 17.7 \mathrm{pg} / \mathrm{mL}$; $P<0.05 ; n=3$ ) (Fig. 3B). C5a concentration returned to control values after longer delays as no significant differences were detected between unstimulated and LPS stimulated fibroblasts after 1 or 24 h (Fig. 3B).

\section{C5a Fixation on Pulp Progenitor Cells}

When pulp progenitor cells were incubated with the culture medium of unstimulated pulp fibroblasts, no C5a labeling was detected on their surface (Fig. 4A). However, when pulp fibroblasts were stimulated with LPS for $20 \mathrm{~min}$ in serum-free medium and the resulting supernatant was added to pulp progenitor cultures, an intense C5a labeling was detected on the surface of these progenitor cells (Fig. 4B). The labeling is clearly visible at a higher magnification (Fig. 4D). No staining was detected in the controls (Fig. 4C).

\section{Human Pulp Fibroblast \\ Stimulation with LPS Induces Progenitor Pulp Cell Recruitment through C5a}

In the absence of pulp fibroblasts in the lower chamber of the migration system, no cell migration was detected (Fig. 5Aa-d). When pulp

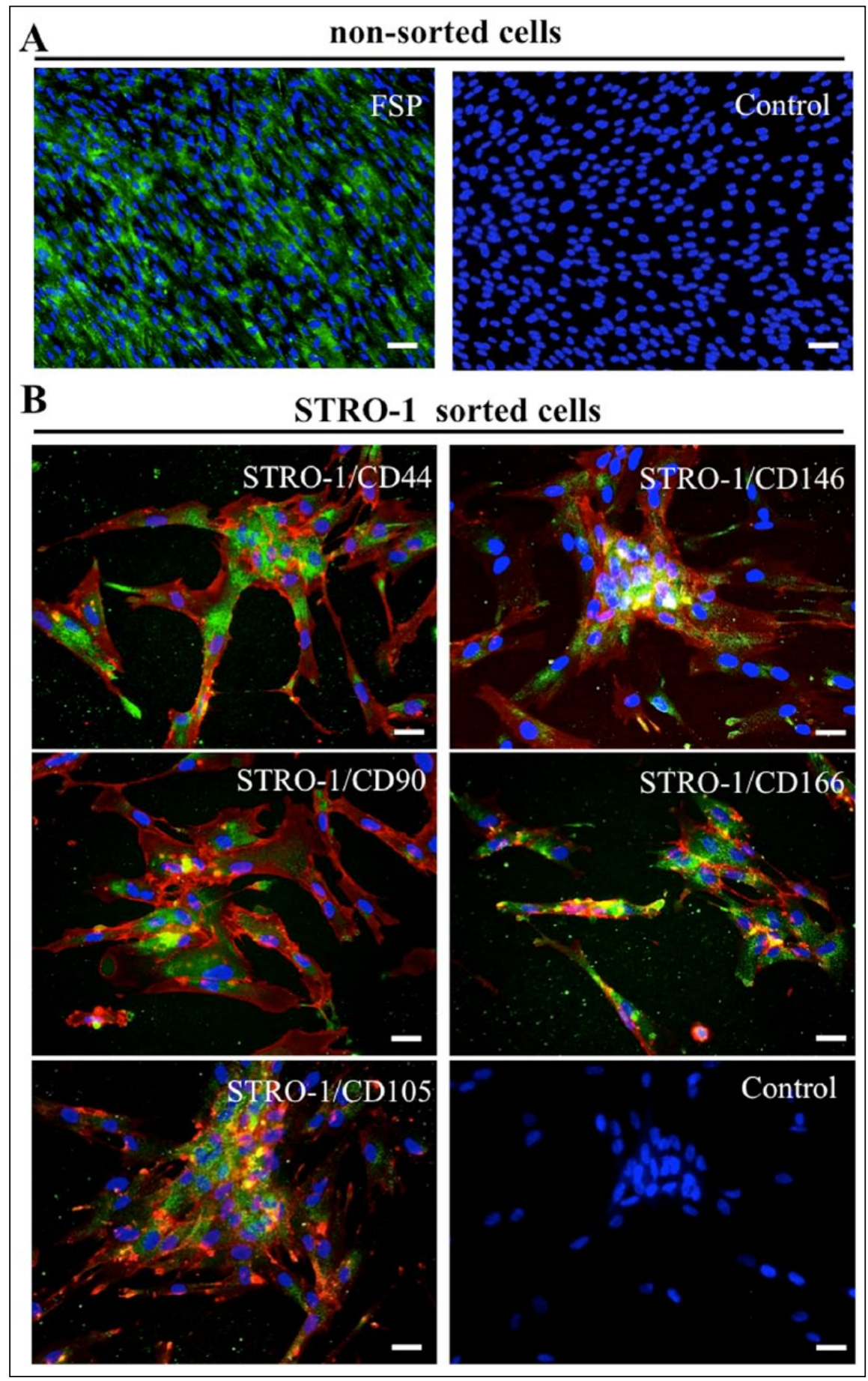

Figure 2. Pulp cell characterization. (A) Fibroblast surface protein (FSP) was detected by immunofluorescence on the surface of all nonsorted human pulp cells. No immunostaining was observed in control conditions with an isotype. (B) Immunofluorescence double staining was used to visualize mesenchymal stem cell markers on STRO-I sorted cells. As indicated in representative microscopic images, the cell population obtained after expansion of STRO-I sorted cells expressed both the mesenchymal stem cell marker STRO-I (green fluorescence) and 5 other stem cell markers: CD44, CD90, CDI05, CDI46, and CDI66 (red fluorescence). No immunostaining was observed in controls. Nuclei were counterstained with DAPI (blue). Scale bars $=50 \mu \mathrm{m}$ (A and B). 


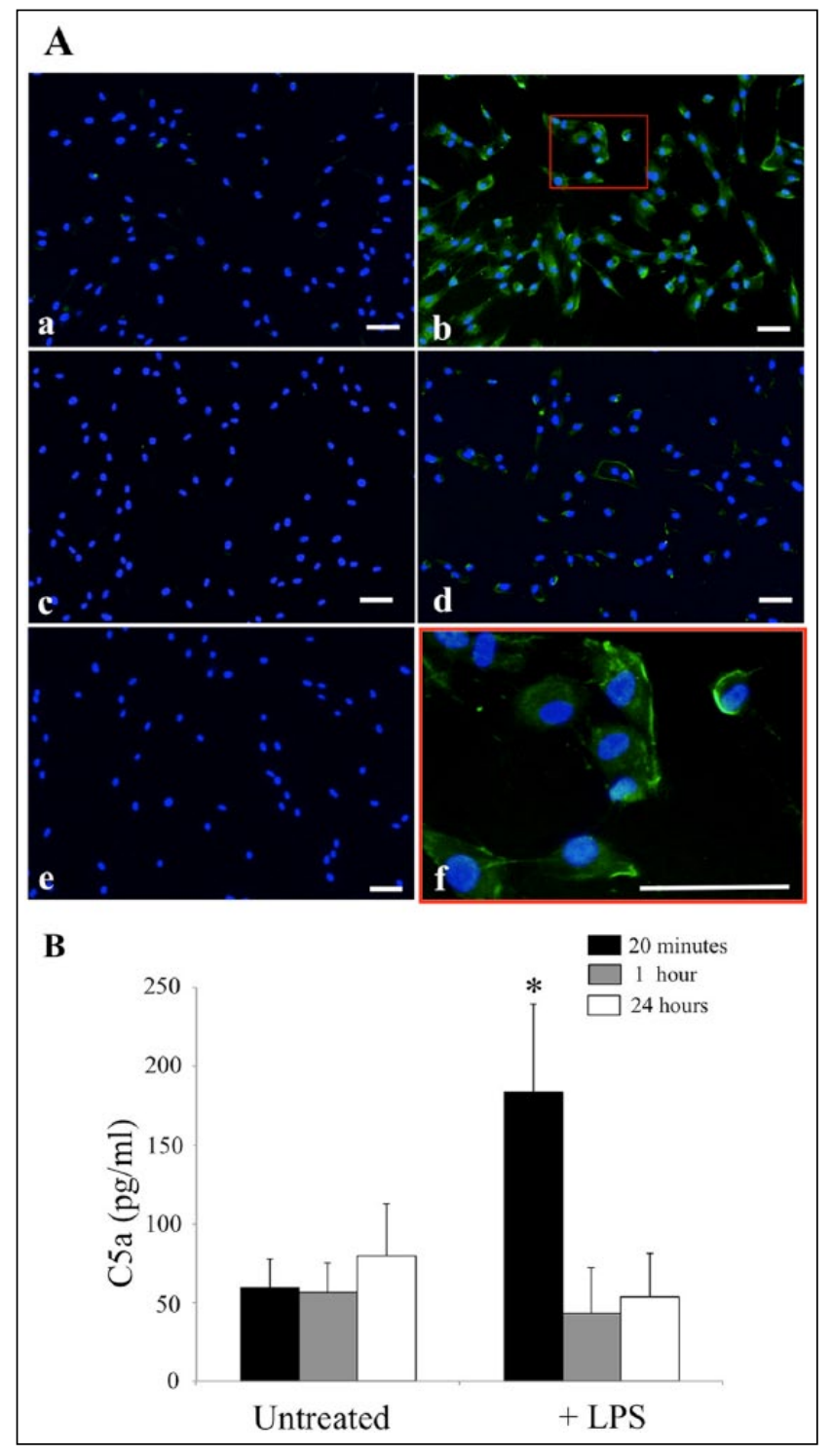

Figure 3. Lipopolysaccharide (LPS) stimulation of human pulp fibroblasts leads to complement system activation. (A) Representative images of membrane attack complex (MAC) immunostaining on unstimulated (a and c) or LPS-stimulated (b, $\mathrm{d}$, e, and $\mathrm{f}$ ) pulp fibroblasts in the absence ( $\mathrm{a}$ and $\mathrm{b}$ ) or presence (c and d) of soluble CD59, a MAC formation inhibitor. While no MAC was observed on unstimulated pulp fibroblasts (a and $c$ ), an intense MAC labeling was detected on LPS-stimulated pulp fibroblasts (b), which is clearly visible at a higher magnification (f). The incubation of pulp fibroblasts with soluble CD59 drastically inhibited the MAC formation on LPS-stimulated fibroblasts (d). Nuclei were counterstained with DAPI (blue) (af). Scale bars: $a-f=50 \mu \mathrm{m}$. (B) C5a complement fragment was detected in human pulp fibroblast supernatants after $20 \mathrm{~min}$ of LPS stimulation. While insignificant concentrations of C5a were detected in the supernatant of untreated cells, LPS stimulation of pulp fibroblasts for 20 min led to a significant increase of $\mathrm{C} 5 \mathrm{a}$ in the supernatant $(183.60 \pm 56.20 \mathrm{pg} / \mathrm{mL}$ vs. $59.8 \pm 17.7 \mathrm{pg} / \mathrm{mL}$; $* P$ $<0.05 ; n=3)$. C5a concentration decreased after longer delays, and no statistically significant difference was found between LPSstimulated and unstimulated cells after I or $24 \mathrm{~h}$. fibroblasts were seeded in the lower chamber, the migration of few progenitor cells was observed (Fig. 5Ae), and adding the C5aR-specific antagonist (W54011) in the upper chamber did not affect their migration (Fig. 5Af). When pulp fibroblasts of the lower chamber were stimulated with LPS, a significant number of pulp progenitor migrating cells were detected (Fig. 5Ag). Interestingly, this number drastically decreased when progenitor cells were coincubated with W54011 (Fig. 5Ah).

Pulp progenitor cell migration analysis (Fig. 5B) confirmed that the number of migrating pulp progenitor cells significantly increased when pulp fibroblasts of the lower chambers were stimulated with LPS $(87.3 \pm 27.0$ vs. $14.7 \pm$ 8.1 unstimulated fibroblasts; $n=3, P<0.05$ ). This migration was significantly reduced by coincubation of pulp progenitor cells with the W54011 (30.1 \pm 16.4 vs. $2.5 \pm 0.8$; $n=3, P<0.05)$. These results indicate that the complement active fragment $\mathrm{C} 5 \mathrm{a}$ induced the migration of pulp progenitor cells via its interaction with $\mathrm{C} 5 \mathrm{aR}$.

\section{Discussion}

In this article, we provide evidence of a plasma-independent activation of complement system. This activation, leading both to the MAC formation and to the biologically active C5a fragment release, was achieved after pulp fibroblast stimulation with LPS in serum-free medium.

It has been established that complement system activation is correlated with the presence of Gram-positive bacteria in carious dentin and pulp tissues (Chmilewsky et al. 2014b). However, several studies have demonstrated that Gramnegative bacteria such as Prevotella and Porphyromonas are also involved in carious injuries (Tokuda et al. 2001; Martin et al. 2002; Silva et al. 2009). Lipopolysaccharide, the main pathogenic factor of all Gram-negative bacteria, is known for its capacity to induce a strong inflammatory response, notably by binding to its specific receptor, Toll-like receptor 4 (TLR4) (Soares et al. 2010). The interaction between LPS and TLR4 leads to the production of pro-inflammatory cytokines and chemokines such as tumor necrosis factor and IL-6 (Soares et al. 2010). Therefore, the presence of Gramnegative bacteria in carious teeth could also explain the increase of these pro-inflammatory mediators in pulp tissue of carious teeth (Mutoh et al. 2007; Farges et al. 2011). Moreover, the inflammatory response induced by Gramnegative bacteria is also known to be involved in the complement system activation through the classical and lectin pathways (Kang et al. 2006; Pangburn et al. 2008). A recent study has demonstrated complement system activation and MAC formation at the injury site of carious teeth (Chmilewsky et al. 2013). While in many tissues, this can be interpreted as a result of complement activation in the plasma, another study has reported that, after LTA stimulation, human pulp fibroblasts are able to produce all proteins required for complement activation (Chmilewsky et al. 2014b). Interestingly, 
our results demonstrated the formation of MAC on pulp fibroblasts after LPS stimulation, which is the ultimate step of complement system activation. Since these experiments were conducted in serum-free conditions (i.e., in the absence of complement proteins from plasma), they clearly demonstrate an activation of complement system from proteins produced by pulp fibroblasts. This is confirmed by the complement active fragment $\mathrm{C} 5 \mathrm{a}$ detection in serum-free culture medium of LPS-stimulated pulp fibroblasts. This C5a fragment is mainly known as a powerful chemotactic factor involved in inflammatory cell recruitment to the damaged/infection site (ElNaggar et al. 1980; Chenoweth and Goodman 1983; Gerard et al. 1989; Werfel et al. 1997) and in the recruitment of a wide range of nonimmune cells (Baghestanian et al. 1996; Nataf et al. 2001; Monk et al. 2007). These chemotactic effects are due to the interaction of $\mathrm{C} 5 \mathrm{a}$ with its active receptor, the C5aR (Schraufstatter et al. 2009). It has been demonstrated that human pulp cells, which express the mesenchymal stem cell marker STRO-1, express also the C5aR and interact with the recombinant C5a (Chmilewsky et al. 2013). In accordance with these data, here we clearly demonstrate that human pulp progenitor cells, which express STRO-1 and 5 other stem cell markers (CD44, CD90, CD105, CD146, and CD166), bind the C5a generated by the complement system activation from pulp fibroblast-produced proteins after LPS stimulation. The interaction between $\mathrm{C} 5 \mathrm{a}$ from plasma and $\mathrm{C} 5 \mathrm{aR}$ has been reported in some regenerative processes (Lara-Astiaso et al. 2012; Mastellos et al. 2001; Ignatius et al. 2011), including dental pulp regeneration (Chmilewsky et al. 2013, 2014a, 2014b). In this study, using a dynamic migration transwell migration assay, we provide a proof of the direct pulp fibroblast implication in the progenitor cell recruitment, which is a crucial step of dentin-pulp regeneration. This recruitment is generated after pulp fibroblast stimulation with LPS and is abolished by the C5aR-specific antagonist, W54011, indicating that the pulp progenitor recruitment is mediated by the $\mathrm{C} 5 \mathrm{a}$ active fragment.
Dentin-pulp regeneration, which occurs after dentinpulp injuries, is regulated by signals liberated after an acid dissolution of the carious dentin (Smith et al. 1995; Graham et al. 2006), by the activation of complement system from plasma (Chmilewsky et al. 2013), or by growth factors released from pulp fibroblasts and endothelial cells in case of traumatic injuries (Tran-Hung et al. 2008; About 2011). Therefore, our results are in agreement with studies demonstrating the ability of pulp fibroblasts to modify the local microenvironment in case of injuries to enhance the local dentin-pulp regeneration (Chmilewsky et al. 2014a). During the progression of tooth decay, odontoblasts are the first cells to be subjected to bacteria and their toxins. It is well established that during superficial carious injuries, there is an upregulation of the odontoblast activity to synthesize a reactionary dentin to prevent the penetration of bacteria and their toxins into the pulp. This work adds to the current knowledge that when the carious injury is deep and when the pulp fibroblasts are affected, they increase their synthetic activity. This includes the synthesis of complement proteins and their activation to recruit the progenitor cells required to establish the dentin bridge. 


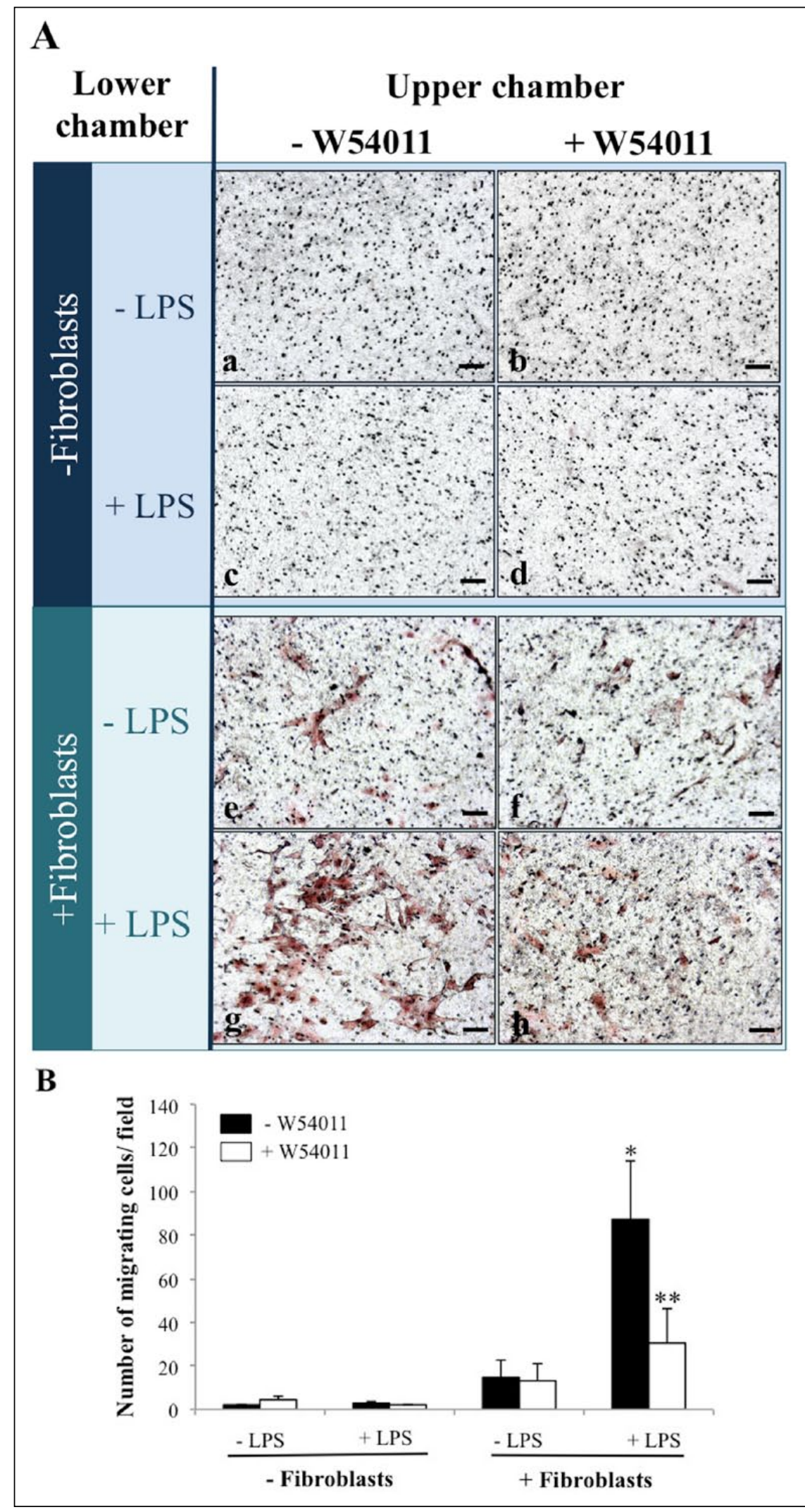

Figure 5. Stimulation of pulp fibroblasts with lipopolysaccharide (LPS) induces progenitor cell recruitment through C5a. (A) Representative images of progenitor cell migration on the lower surface of the porous membrane after $24 \mathrm{~h}$. Cell migration
Taken together, our work demonstrates, for the first time, a direct interaction between the recruitment of progenitor pulp cells and the activation of complement system generated by LPS stimulation of human pulp fibroblasts. This may provide a useful future therapeutic tool in targeting the pulp fibroblasts in the dentin-pulp regeneration process.

\section{Author Contributions}

F. Chmilewsky, contributed to conception, design, data acquisition, analysis, and interpretation, drafted and critically revised the manuscript; C. Jeanneau, contributed to data acquisition, analysis and interpretation, critically revised the manuscript; P. Laurent, contributed to data analysis and interpretation, critically revised the manuscript; I. About, contributed to conception, design, data analysis, and interpretation, drafted and critically revised the manuscript. All authors gave final approval and agree to be accountable for all aspects of the work.

was not observed in the absence of pulp fibroblasts in the lower chamber $(a-d)$. The migration of few progenitor cells was observed when pulp fibroblasts were plated in the lower chambers (e). The number of migrating cells did not seem to be affected by the coincubation of progenitor cells with the C5aR-specific antagonist W540 I I (f). However, when pulp fibroblasts in the lower chamber were stimulated with LPS, a significant number of migrating progenitor cells were observed $(\mathrm{g})$. This number decreased when progenitor cells were coincubated with W540 I I (h). Scale bars: $a-f=50 \mu \mathrm{m}$. (B) C5a generated by LPS stimulation of pulp fibroblasts induces pulp progenitor cell migration. Transwell cell migration in the histogram is expressed as the number of migrating progenitor cells per field \pm SEM. When pulp fibroblasts were plated in the lower chamber and stimulated with LPS, the number of migrating progenitor cells was significantly higher $\left(^{*}\right)$ than in the other cases $(P<0.05)$. When progenitor cells were coincubated with W540II, the number of migrating cells decreased significantly $(* *)(P<0.05)$. 


\section{Acknowledgments}

The authors thank Dr. Jean-Charles Gardon for providing the third molars used in this work. This work was supported by funding from Aix-Marseille University, and CNRS and partial support from European Society of Endodontology through the annual research grant (2012-121) to I. About. The authors declare no potential conflicts of interest with respect to the authorship and/or publication of this article.

\section{References}

About I. 2011. Dentin regeneration in vitro: the pivotal role of supportive cells. Adv Dent Res. 23(3):320-324.

About I, Bottero MJ, Denato P, Camps J, Franquin JC, Mitsiadis TA. 2000. Human dentin production in vitro. Exp Cell Res. 258(1):33-41.

Alper CA, Johnson AM, Birtch AG, Moore FD. 1969. Human C'3: evidence for the liver as the primary site of synthesis. Science. 163(3864):286-288.

Baghestanian M, Bankl HC, Sillaber C, Beil WJ, Radaszkiewicz T, Füreder W, Preiser J, Vesely M, Schernthaner G, Lechner $\mathrm{K}$, et al. 1996. A case of malignant mastocytosis with circulating mast cell precursors: biologic and phenotypic characterization of the malignant clone. Leukemia. 10(1):159-166.

Chenoweth DE, Goodman MG. 1983. The C5a receptor of neutrophils and macrophages. Agents Actions Suppl. 12:252-273.

Chmilewsky F, Jeanneau C, Dejou J, About I. 2014a. Sources of dentin-pulp regeneration signals and their modulation by the local microenvironment. J Endod. 40(4, Suppl):S19-S25.

Chmilewsky F, Jeanneau C, Laurent P, About I. 2014b. Pulp fibroblasts synthesize functional complement proteins involved in initiating dentin-pulp regeneration. Am J Pathol. 184(7):1991-2000.

Chmilewsky F, Jeanneau C, Laurent P, Kirschfink M, About I. 2013. Pulp progenitor cell recruitment is selectively guided by a C5a gradient. J Dent Res. 92(6):532-539.

Ehrengruber MU, Geiser T, Deranleau DA. 1994. Activation of human neutrophils by $\mathrm{C} 3 \mathrm{a}$ and $\mathrm{C} 5 \mathrm{~A}$ : comparison of the effects on shape changes, chemotaxis, secretion, and respiratory burst. FEBS Lett. 346(2-3):181-184.

El-Naggar AK, Van Epps DE, Williams RC. 1980. Human-B and T-lymphocyte locomotion in response to casein, C5a, and f-met-leu-phe. Cell Immunol. 56(2):365-373.

Farges JC, Carrouel F, Keller JF, Baudouin C, Msika P, Bleicher F, Staquet MJ. 2011. Cytokine production by human odontoblast-like cells upon Toll-like receptor-2 engagement. Immunobiology. 216(4):513-517.

Gerard NP, Hodges MK, Drazen JM, Weller PF, Gerard C. 1989. Characterization of a receptor for $\mathrm{C} 5 \mathrm{a}$ anaphylatoxin on human eosinophils. J Biol Chem. 264(3):1760-1766.

Graham L, Cooper PR, Cassidy N, Nor JE, Sloan AJ, Smith AJ. 2006. The effect of calcium hydroxide on solubilisation of bio-active dentine matrix components. Biomaterials. 27(14):2865-2873.

Hartmann K, Henz BM, Krüger-Krasagakes S, Köhl J, Burger R, Guhl S, Haase I, Lippert U, Zuberbier T. 1997. C3a and C5a stimulate chemotaxis of human mast cells. Blood. 89(8):2863-2870.
Ignatius A, Ehrnthaller C, Brenner RE, Kreja L, Schoengraf P, Lisson P, Blakytny R, Recknagel S, Claes L, Gebhard F, et al. 2011. The anaphylatoxin receptor $\mathrm{C} 5 \mathrm{aR}$ is present during fracture healing in rats and mediates osteoblast migration in vitro. J Trauma. 71(4):952-960.

Kang YS, Do Y, Lee HK, Park SH, Cheong C, Lynch RM, Loeffler JM, Steinman RM, Park CG. 2006. A dominant complement fixation pathway for pneumococcal polysaccharides initiated by SIGN-R1 interacting with C1q. Cell. 125(1):47-58.

Kenneth M, Travers P, Walport M, Janeway C. 2012. Janeway's immunobiology. 8th ed. New York: Garland Science.

Lara-Astiaso D, Izarra A, Estrada JC, Albo C, Moscoso I, Samper E, Moncayo J, Solano A, Bernad A, Díez-Juan A. 2012. Complement anaphylatoxins $\mathrm{C} 3 \mathrm{a}$ and $\mathrm{C} 5 \mathrm{a}$ induce a failing regenerative program in cardiac resident cells: evidence of a role for cardiac resident stem cells other than cardiomyocyte renewal. Springerplus. 1(1):63.

Li K, Sacks SH, Zhou W. 2007. The relative importance of local and systemic complement production in ischaemia, transplantation and other pathologies. Mol Immunol. 44(16):3866-3874.

Loesche WJ. 1986. Role of Streptococcus mutans in human dental decay. Microbiol Rev. 50(4):353-380.

Martin FE, Nadkarni MA, Jacques NA, Hunter N. 2002. Quantitative microbiological study of human carious dentine by culture and real-time PCR: association of anaerobes with histopathological changes in chronic pulpitis. J Clin Microbiol. 40(5):1698-1704.

Mastellos D, Papadimitriou JC, Franchini S, Tsonis PA, Lambris JD. 2001. A novel role of complement: mice deficient in the fifth component of complement (C5) exhibit impaired liver regeneration. J Immunol. 166(4):2479-2486.

Monk PN, Scola AM, Madala P, Fairlie DP. 2007. Function, structure and therapeutic potential of complement $\mathrm{C} 5 \mathrm{a}$ receptors. Br J Pharmacol. 152(4):429-448.

Mutoh N, Tani-Ishii N, Tsukinoki K, Chieda K, Watanabe K. 2007. Expression of Toll-like receptor 2 and 4 in dental pulp. J Endod. 33(10):1183-1186.

Nataf S, Davoust N, Ames RS, Barnum SR. 1999. Human T cells express the C5a receptor and are chemoattracted to C5a. J Immunol. 162(7):4018-4023.

Nataf S, Levison SW, Barnum SR. 2001. Expression of the anaphylatoxin C5a receptor in the oligodendrocyte lineage. Brain Res. 894(2):321-326.

Pangburn MK, Ferreira VP, Cortes C. 2008. Discrimination between host and pathogens by the complement system. Vaccine. 26(Suppl 8):15-21.

Ricklin D, Hajishengallis G, Yang K, Lambris JD. 2010. Complement: a key system for immune surveillance and homeostasis. Nat Immunol. 11(9):785-797.

Sarma JV, Ward PA. 2011. The complement system. Cell Tissue Res. 343(1):227-235.

Schraufstatter IU, Discipio RG, Zhao M, Khaldoyanidi SK. 2009. $\mathrm{C} 3 \mathrm{a}$ and $\mathrm{C} 5 \mathrm{a}$ are chemotactic factors for human mesenchymal stem cells, which cause prolonged ERK1/2 phosphorylation. J Immunol. 182(6):3827-3836.

Shi S, Gronthos S. 2003. Perivascular niche of postnatal mesenchymal stem cells in human bone marrow and dental pulp. J Bone Miner Res. 18(4):696-704. 
Silva AC, Faria MR, Fontes A, Campos MS, Cavalcanti BN. 2009. Interleukin-1 beta and interleukin- 8 in healthy and inflamed dental pulps. J Appl Oral Sci. 17(5):527-532.

Smith AJ, Tobias RS, Cassidy N, Bégue-Kirn C, Ruch JV, Lesot H. 1995. Influence of substrate nature and immobilization of implanted dentin matrix components during induction of reparative dentinogenesis. Connect Tissue Res. 32(1-4):291296.

Soares JB, Pimentel-Nunes P, Roncon-Albuquerque R, LeiteMoreira A. 2010. The role of lipopolysaccharide/Toll-like receptor 4 signaling in chronic liver diseases. Hepatol Int. 4(4):659-672.

Téclès O, Laurent P, Zygouritsas S, Burger AS, Camps J, Dejou J, About I. 2005. Activation of human dental pulp progenitor/ stem cells in response to odontoblast injury. Arch Oral Biol. 50(2):103-108.
Tokuda M, Sakuta T, Fushuku A, Torii M, Nagaoka S. 2001. Regulation of interleukin-6 expression in human dental pulp cell cultures stimulated with Prevotella intermedia lipopolysaccharide. J Endod. 27(4):273-277.

Tomlinson S. 1993. Complement defense mechanisms. Curr Opin Immunol. 5(1):83-89.

Tran-Hung L, Laurent P, Camps J, About I. 2008. Quantification of angiogenic growth factors released by human dental cells after injury. Arch Oral Biol. 53(1):9-13.

Werfel T, Oppermann M, Begemann G, Götze O, Zwirner J. 1997. C5a receptors are detectable on mast cells in normal human skin and in psoriatic plaques but not in weal and flare reactions or in uticaria pigmentosa by immunohistochemistry. Arch Dermatol Res. 289(2):83-86.

Würzner R. 2000. Modulation of complement membrane attack by local C7 synthesis. Clin Exp Immunol. 121(1):8-10. 